MA'ALIM: Jurnal Pendidikan Islam

Volume 1, Nomor 1, Juli 2020

\title{
KONSEP SAKINAH MAWADDAH WA RAHMAH MENURUT M. QURAISH SHIHAB DAN RELEVANSINYA TERHADAP PENDIDIKAN ANAK DALAM KELUARGA
}

\author{
Anist Suryani \\ IAIN Ponorogo \\ anistsuryani@gmail.com
}

\author{
Kadi \\ IAIN Ponorogo \\ kadiabuzakaria@gmail.com
}

\begin{abstract}
Family has a very big contribution in children's education. Because the family is the first environment for children. Basically, children are born to bring fitrah to good beliefs, that's where the family plays a role, especially parents who focus on and strengthen children's beliefs through education. For this reason, if we want to shape children's education with good education, it must begin at the time of family formation. Because a good family will continue a good generation. A good family according to Islam is the one that is sure to be mawaddah wa rahmah. The results of the study found that the concept of Sakinah Mawaddah Wa Rahmah according to M. Quraish Shihab is relevant to children's education because families that use the concept of sakinah mawaddah wa rahmah are families who are able to form good education for their children. Based on the process of relations between family and children, both underlie the relationship with the feeling of love and love. As well as to form a quality education, it starts from forming a family that is sakinah mawaddah wa rahmah. However, it is needed to study more about family concepts, with the aim of increasing and instilling child education starting with the family, because the family is the first institution to instill education in children.
\end{abstract}

Keywords: Children education, concept of sakinah, concept of mawaddah, concept of rahmah, family education.

Abstrak: Keluarga mempunyai andil yang sangat besar dalam pendidikan anak. Sebab keluarga merupakan lingkungan pertama yang dikenal anak. Pada dasarnya anak lahir membawa fitrah pada keyakinan yang baik, disitulah peran keluarga, utamanya orang tua yang megarahkah dan memantapkan keyakinan anak melalui pendidikan. Untuk itu, jika ingin membentuk pendidikan anak dengan pendidikan yang baik maka harus dimulai pada saat pembetukan keluarga. Karena keluarga yang baik akan meneruskan generasi yang baik. Keluarga yang baik menurut Islam adalah yang sakinah mawaddah wa rahmah. Hasil penelitian menemukan bahwa konsep Sakinah Mawaddah Wa Rahmah menurut M. Quraish Shihab relevan dengan pendidikan anak sebab keluarga yang menggunakan konsep sakinah mawaddah wa rahmah adalah keluarga yang mampu membentuk pendidikan yang baik untuk anak-anak mereka. Berdasarkan proses relasi antara keluarga dengan anak, sama-sama mendasari hubungan dengan rasa cinta dan kaih sayang. Serta untuk membentuk pendidikan yang berkualitas maka berawal dari membentuk keluarga yang sakinah mawaddah wa rahmah. Namun demikian, diperlukan lebih benyak penelitian yang mengkaji mengenai konsep-konsep keluarga, dengan tujuan untuk meningkatkan serta menanamkan pendidikan anak yang dimulai dari keluarga, sebab keluarga adalah lembaga pertama menanamkan pendidikan pada anak.

Kata kunci: Konsep sakinah, konsep mawaddah, konsep rahmah, pendidikan anak, pendidikan keluarga, 
MA'ALIM: Jurnal Pendidikan Islam

Volume 1, Nomor 1, Juli 2020

\section{PENDAHULUAN}

Pernikahan adalah akad yang menghalalkan pergaulan dan membatasi hak dan kewajiban seorang laki-laki dan seorang perempuan yang bukan mahram. ${ }^{1}$ Menurut Kompilasi Hukum Islam (KHI) pasal 2 bahwa pernikahan adalah suatu akad yang sangat kuat atau mithaqan ghalizan, untuk menaati perintah Allah dan melaksanakannya merupakan Ibadah. ${ }^{2}$

Tujuan dekat sebuah pernikahan untuk setiap pasangan adalah meraih sakinah melalui pengembangan potensi mawaddah dan rahmah, sedangkan tujuan akhirnya adalah melaksanakan tugas kekhalifahan dalam pengabdian kepada Allah Swt. sehingga lahir fungsi-fungsi yang harus diemban oleh keluarga. ${ }^{3}$ Selain itu tujuan berumah tangga adalah untuk mencapai ketentraman jiwa dan meraih kebahagiaan serta kelanggengan rumah tangga. Lebih dari itu, tujuan pernikahan adalah menumbuhkan perpaduan kasih sayang, keadilan dan persamaan baik antara suami isteri maupun seluruh anggota keluarga. ${ }^{4}$

Pondasi ideal dan cita pernikahan dalam Islam sebagaimana dilukiskan dalam ayat alQur'an surat al-ruum ayat 21:

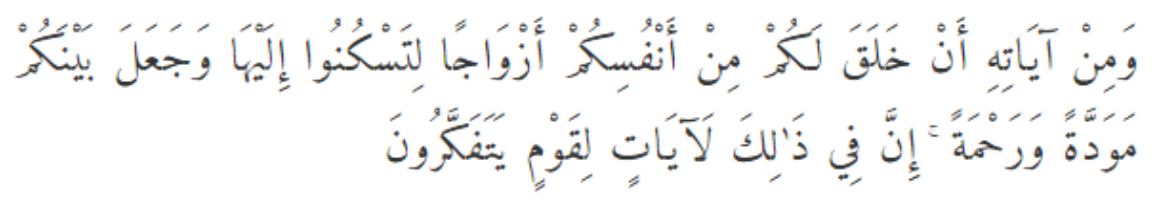

Artinya: "Dan di antara tanda-tanda kekuasaan-Nya ialah Dia menciptakan untukmu isteri-isteri dari jenismu sendiri, supaya kamu cenderung dan merasa tenteram kepadanya, dan dijadikan-Nya diantaramu rasa kasih dan sayang. Sesungguhnya pada yang demikian itu benar-benar terdapat tanda-tanda bagi kaum yang berfikir." (QS. al-Ruum: 21).

Kandungan ayat ini menggambarkan bahwa pernikahan dalam Islam idealnya melahirkan jalinan ketentraman (sakinah), rasa kasih dan rasa sayang sebagai suatu ketenangan yang dibutuhkan oleh masing-masing pasangan. Oleh karena itu, pernikahan dalam Islam diharapkan dapat terciptanya keluarga sakinah, mawaddah wa rahmah. ${ }^{6}$

\footnotetext{
${ }^{1}$ Beni Ahmad Saebani, Fiqh Munakahat 1. Cet. IV (Bandung: CV Pustaka Setia, 2009), 9.

${ }^{2}$ Ibid, 15. 2007), 80 .

${ }^{3}$ M. Quraish Shihab, Pengantin Al-Qur'an; Kalung Permata Buat Anak-anakku (Jakarta: Lentera Hati,

${ }^{4}$ Badan Litbang dan Diklat Kementrian Agama RI, Keluarga Harmoni dalam Perspektifberbagai Komunitas Agama di Indonesia (Jakarta: Puslitbang Kehidupan Keagamaan Badan Litbang dan Diklat Kementrian Agama RI, 2011), 14.

${ }^{5}$ Departemen Agama RI, Al-Qur'an dan Tafsirnya Jilid VII (Departemen Agama RI, 2009), 477.

${ }^{6}$ Yusdani, Menuju Fiqih Keluarga Progresif (Yogyakarta: Kaukaba, 2015), 177.
} 
MA'ALIM: Jurnal Pendidikan Islam

Volume 1, Nomor 1, Juli 2020

Sakinah mawaddah wa rahmah adalah ungkapan yang sangat populer di kalangan anak muda, pengantin baru bahkan mereka yang berpuluh tahun menikah. Ungkapan yang mengandung harapan ini senantiasa didengungkan ketika seseorang memasuki jenjang pernikahan, dan disampaikan berulang-ulang dalam rangkaian upacara pernikahan. Hal ini menunjukkan bahwa keluarga sakinah adalah impian setiap orang. ${ }^{7}$

Pada umumnya keluarga sakinah dipahami sebagai keluarga yang tenteram dengan suami yang baik dan bertanggungjawab dan isteri yang setia dan penuh kasih sayang serta anak-anak yang berbakti. ${ }^{8}$ Menurut M. Quraish Shihab konsep keluarga sakinah adalah keluarga yang tenang dan penuh kasih sayang untuk dapat melahirkan mawaddah dan rahmah. ${ }^{9}$

Muhammad Quraish Shihab adalah seorang ulama yang lahir pada 16 Pebruari 1944 di Rappang Sulawesi Selatan. ${ }^{10}$ Beliau dilahirkan dan dibesarkan dalam lingkungan muslim yang sangat taat dalam beragama. Beliau sangat menghormati kedua orang tuanya, ayah beliau bernama Abdurrahman Shihab seorang ulama keturunan dari Arab yang terpelajar dan guru besar Tafsir di IAIN Alaudin, Ujung Pandang. ${ }^{11}$ Beliau mendapatkan pendidikan yang baik di dalam keluarganya yang diberikan oleh kedua orang tuanya, hingga beliau dapat melanjutkan studi lebih tinggi. Dari sedikit cuplikan kisah M. Quraish Shihab dapat kita ambil pelajaran bahwa setiap anak berhak memperoleh pendidikan yang baik yang diberikan oleh kedua orang tuanya dalam keluarga. Sebab keluarga merupakan lingkungan pertama dan utama bagi tumbuh dan berkembangnya seorang anak.

Pendidikan adalah bimbingan atau pertolongan yang diberikan dengan sengaja oleh orang dewasa agar anak menjadi dewasa. ${ }^{12}$ Rasulullah Saw. bersabda yang artinya: "Setiap anak itu dilahirkan dalam keadaan suci." Beliau memberikan contoh bahwa lingkungan pertama bagi seorang anak adalah kedua orang tuanya. Lalu beliau bersabda yang artinya: "Kedua Ibu Bapaknyalah yang membuat ia menjadi Nasrani atau Majusi." Sedangkan gelar yang paling baik dari pendidikan anak di keluarga bukan gelar akademis, melainkan gelar sebagai waladan salihah,

\footnotetext{
${ }^{7}$ Badan Litbang dan Diklat Kemenag RI, Modul Keluarga Sakinah Berperspektif Kesetaraan bagi penghulu, Penyuluh, dan Konselor BP4 (Jakarta: Badan Litbang dan Diklat Kementrian Agama RI, ), xli.

${ }^{8}$ Badan Litbang dan Diklat Kementrian Agama RI, Keluarga Harmoni, 14.

${ }^{9}$ Shihab, Pengantin Al-Qur'an, 174-175

${ }^{10}$ Lihat kata penutup M. Quraish Shihab, Tafsir al-Mishbāh: Pesan, Kesan dan Keserasian al-Qur'an, vol. 1, cetakan V (Jakarta: Lentera Hati, 2006).

${ }^{11}$ Abuddin Nata, Tokoh-tokoh Pembaharuan Pendidikan Islam Di Indonesia (Jakarta: Raja Grafindo Press), 362.

${ }^{12}$ Hasbullah, Dasar-dasar Ilmu Pendidikan (Jakarta: PT Raja Grafindo Persada, 2005), 1.
} 
MA'ALIM: Jurnal Pendidikan Islam

Volume 1, Nomor 1, Juli 2020

yakni anak yang salih. Sejarah kehidupan yang membuktikan bahwa proses pendidikan di rumah sangat menentukan bukan saja bagi kehidupan anak itu sendiri, melainkan juga bagi perjalanan kehidupan manusia pada umumnya. ${ }^{13}$

Beragam perilaku orang tua dan anggota keluarga yang lain di dalam menyikapi belajar anak dipengaruhi oleh beberapa faktor, yaitu: faktor budaya, faktor latar belakang pendidikan, faktor minat, dan faktor pengaruh lingkungan. Budaya belajar ditentukan turun-temurun oleh suatu keluarga. Dalam keluarga yang orang tuanya membudayakan belajar, maka anak-anaknya akan lebih suka mempergunakan waktu untuk membaca dan belajar, sebaliknya jika orang tua kurang memperdulikan budaya belajar anak, maka akibatnya anakpun akan lebih senang menggunakan waktunya untuk bermain dan mencari hiburan. ${ }^{14}$

Memiliki keluarga sakinah serta anak yang salih memerlukan proses panjang. Proses tersebut dimulai sebelum kelahiran sang anak bahkan sebelum dilangsungkanya pernikahan, karena ketika sang anak lahir, ayah dan ibu dapat saling membantu mewujudkan keluarga yang Islami demi pendidikan buah hatinya. Salah satu kekeliruan orang tua adalah mengharapkan anaknya menjadi anak yang salih dengan memasukkan anaknya ke sekolah Islam, namun melupakan faktor-faktor yang semestinya dilakukan sebelum kelahiran sang anak. ${ }^{15}$

Dalam membangun sebuah keluarga tidaklah semudah yang kita bayangkan. Sebab di dalam rumah tangga pastilah ada konflik yang tentunya harus dihadapi dan diselesaikan oleh anggota keluarga itu sendiri. Misal seperti persoalan tentang anak yang kurang diperhatikan pendidikannya, belum terpenuhinya hak dan kewajiban masing-masing anggota, kurangnya kasih sayang, atau mungkin masalah adanya perbedaan dari masing-masing yang seharusnya dijadikan pelengkap antara satu sama lain dan sebagainya.

Beberapa masalah tersebut terjadi, mungkin karena terlupakannya makna dari tujuan pernikahan itu sendiri. Dan tidak lupa, bahwa di dalam keluarga juga memiliki anak yang membutuhkan pendidikan yang baik dari orang tua dan anggota keluarga yang lain. Sebab anak petama kali tumbuh dan berkembang di dalam lingkungan keluarga.

\footnotetext{
${ }^{13}$ Badri Khaeruman, Moralitas Islam (Bandung: CV Pustaka Setia, 2003), 181

${ }^{14}$ Sofyan S. Willis, Konseling Keluarga (Bandung: Alfabeta, 2013), 174.

${ }^{15}$ M. Fauzi Rachman, Islamic Parenting (Jakarta: Erlangga, 2011), 26.
} 
MA'ALIM: Jurnal Pendidikan Islam

Volume 1, Nomor 1, Juli 2020

Dari uraian di atas sebagai pijakan latar belakang masalah, penulis tertarik dan menganggap penting untuk mengkaji konsep keluarga muslim (Sakinah Mawaddah Wa Rahmah) dan direlevansikan bagi pendidikan anak dalam keluarga.

\section{BIOGRAFI M. QURAISH SHIHAB}

Muhammad Quraish Shihab lahir pada 16 Pebruari 1944 di Rappang Sulawesi Selatan. Ia putra dari Abdurrahman Shihab seorang guru dalam bidang tafsir dan pernah menjadi rektor IAIN Alauddin, serta tercatat sebagai salah satu pendiri Universitas Muslim Indonesia (UMI) di Ujung Pandang. Shihab, selain mengenyam pendidikan di Ujung Pandang ia juga digembleng ayahnya untuk mempelajari Al-Qur'an. ${ }^{16}$ Quraish Shihab menempuh pendidikan Sekolah Dasarnya di Ujung Pandang. Setelah pendidikan dasarnya selesai kemudian melanjutkan pendidikan menengahnya di Malang sambil "Nyantri” di pondok pesantren Darul Hadits al-Faqihiyah. Diduga bahwa faham keberagamaan yang berkembang di sana adalah faham Ahl al-Sunnah wa al-Jama 'ah. ${ }^{17}$

Pada tahun 1958, Shihab berangkat ke Kairo Mesir atas bantuan beasiswa dari Pemerintah Sulawesi Selatan. Ia diterima di kelas II Tsanawiyah di Al-Azhar. Kemudian pada tahun 1967 pendidikan Strata Satu diselesaikan di Universitas Al-Azhar Fakultas Ushuluddin Jurusan Tafsir Hadits. Pada tahun 1969 gelar MA diraihnya di Universitas yang sama. ${ }^{18}$ Setelah menyelesaikan Studi Masternya M. Quraish Shihab kembali ke daerah asalnya Ujung Pandang dan langsung bergabung sebagai staf pengajar di IAIN Alauddin Ujung Pandang mengajar mata kuliah Tafsir dan Ilmu Kalam. Dan kemudian diberi kepercayaan menjabat Wakil Rektor bidang Akademik dan Kemahasiswaan dan juga diberi jabatan-jabatan lain baik di lingkungan kampus maupun di luar lingkungan kampus.

Sepuluh tahun lamanya M. Quraish Shihab mengabdikan dirinya sebagai staf di IAIN Alauddin Ujung Pandang dan mendarma-baktikan ilmunya kepada masyarakat Sulawesi Selatan pada umumnya. Pada tahun 1980 dia pun kembali ke Kairo, Mesir untuk melanjutkan studi Doktor di Almamaternya Universitas Al-Azhar. Setelah dua tahun studinya diselesaikannya dengan disertasi yang berjudul Nizm al-Durar li al-Biqa'i: Tahqiq wa Dirasah, dan berhasil meraih gelar

${ }^{16}$ Lihat kata penutup M. Quraish Shihab, Tafsir al-Mishbāh: Pesan, Kesan dan Keserasian al-Qur'an, vol. 1, cetakan V (Jakarta: Lentera Hati, 2006).

${ }^{17}$ Mustafa, M. Quraish Shihab Membumikan Kalam di Indonesia (Yogyakarta: Pustaka Pelajar, 2010), 64.

${ }^{18}$ Lihat kata penutup M. Quraish Shihab, Tafsir al-Mishbāh. 
MA'ALIM: Jurnal Pendidikan Islam

Volume 1, Nomor 1, Juli 2020

Doktor dalam ilmu-ilmu al-Qur'an dengan yudisium Summa Cum Laude disertai penghargaan Tingkat pertama. Dengan demikian selama 13 tahun di bawah bimbingan dan asuhan Unversitas Al-Azhar secara keseluruhan M. Quraish Shihab telah menjalani pengembangan intelektualnya. Maka iklim tradisi keilmuan dalam studi Islam di lingkungan Al-Azhar itu mempunyai pengaruhpengaruh tertentu terhadap kecenderungan intelektual dan corak pemikiran keagamaan M. Quraish Shihab. Tetapi di samping itu Pondok Pesantren Darul Hadits al-Faqihiyah dan Madrasah Tsanawiyah Malang, serta pendidikan Sekolah Dasar di Ujung Pandang tidak boleh diabaikan sebab M. Quraish Shihab memperoleh basis intelektual dari sana, juga dari lingkungan keluarga, khususnya dari ayahnya. Dia sendiri mengakui bahwa ayahnya memiliki pengaruh begitu mendalam bagi dirinya. ${ }^{19}$

Setelah selesai meraih gelar doktornya, M. Quraish Shihab kembali ke tempat tugas semula, IAIN Alauddin Ujung Pandang. Pada periode kedua ia di IAIN Ujung Pandang berhasil menulis karya berjudul Tafsir al-Manar: Keistimewaan dan Kelemahannya (Ujung Pandang: IAIN Ujung Pandang, 1984). Tidak sampai dua tahun, kemudian ia ditugaskan ke Fakultas Ushuluddin dan Fakultas Pasca sarjana IAIN Syarif Hidayatullah Jakarta. Berbeda dengan Ujung Pandang, di Jakarta suasana akademisnya menawarkan banyak tantangan tapi juga menampilkan sejumlah dinamika intelektual dan keilmuannya. Dan pada kenyataannya M. Quraish Shihab dapat merespon tantangan dan peluang kehidupan akademisnya secara cerdas dan bertanggung jawab. ${ }^{20}$

Karena kecerdasannya Shihab memiliki banyak karya dan pemikiran yang ia tuangkan dalam buku-bukunya, di antara karya-karyanya sebagai berikut: Filsafat Hukum Islam (Jakarta: Departemen Agama, 1987), Mahkota Tuntunan Ilahi (Tafsir Surat Al-Fatihah) (Jakarta: Utgama 1988), Membumikan Al-Qur;an (1992), Lentera Hati (1994), Untaian Permata Buat Anakku (1995), Wawasan Al-Qur'an (1996), Mu'jizat Al-Qur'an (1997), Sahur Bersama (1997), Tafsir Al-Qur'an al-Karim (1997), Menyingkap Tabir Ilahi (1998), Fatwa-fatwa Seputar Ibadah dan Mu'amalah (1999), Fatwa-fatwa Seputar Ibadah Mahdah (1999), dan Fatwa-Fatwa Seputar Agama (1999) ${ }^{21}$ dan masih banyak lagi karya-karyanya. Seting sosial karya-karyanya mencakup masyarakat awam dan kaum terpelajar. Jadi, karya-karyanya atau pemikirannya dapat diterima oleh masyarakat muslim awam dan juga masyarakat muslim terpelajar di Indonesia.

\footnotetext{
${ }^{19}$ Mustafa, M. Quraish Shihab Membumikan Kalam..65-70.

${ }^{20}$ Ibid, 71-72.

${ }^{21}$ Ibid,72-73.
} 
MA'ALIM: Jurnal Pendidikan Islam

Volume 1, Nomor 1, Juli 2020

\section{ANALISIS KONSEP SAKINAH MAWADDAH WA RAHMAH PEMIKIRAN M. QURAISH SHIHAB}

Tidak ada kehidupan yang berjalan mulus, pasti ada rintangan dan tantangan dalam mengarungi kehidupan. Hal ini berlaku dalam hidup berkeluarga. Pasti ada yang namanya rintangan atau konflik, seperti kesalahpahaman antar suami isteri. Untuk itu diperlukan adanya penyelesaian dan penanggulangan masalah, agar keluarga menjadi sakinah/tenang dan tentram.

M. Quraish Shihab memaparkan sakinah adalah ketenangan yang dinamis dan aktif. ${ }^{22}$ Yaitu sebuah ketenangan dalam keluarga yang diperoleh setelah adanya gejolak yang terjadi sebelumnya. ${ }^{23}$ Berdasarkan teori keluarga dalam pendekatan sistem, bahwa kunci kelanggengan keluarga adalah keberhasilan pasangan dalam melakukan penyesuaian yang bersifat dinamis, penyesuaian ini ditandai dengan kebermampuan pasangan dalam melakukan resolusi konflik dengan sikap dan cara konstruktif.

Jadi, peneliti menarik kesimpulan bahwa sakinah adalah konsep keluarga bahagia yang memperoleh ketenangan setelah adanya gejolak atau konflik maupun kesalahpahaman dalam keluarga, yang kemudian dapat diselesaikan dengan baik oleh kedua pasangan. Keluarga yang tenang bukan keluarga tanpa masalah, melainkan keluarga yang mampu keluar di masalah agar dapat mencapai ketenangan tersebut. Menurut Islam keluarga sakinah adalah keluarga tenang dan penuh kasih sayang untuk dapat melahirkan mawaddah dan rahmah. Tali pengikat keluarga dikatakan sakinah adalah adanya mawaddah dan rahmah.

Mawaddah menurut M. Quraish Shihab bukan sekedar cinta, mawaddah adalah "Cinta Plus" yang sejati. ${ }^{24}$ Bukan sekedar cinta yang ketika hatinya kesal, cintanya menjadi pudar. Tetapi yang hatinya telah bersemai mawaddah, tidak akan mudah memutuskan hubungan begitu saja. Ini disebabkan hatinya begitu lapang dan kosong dari keburukan. ${ }^{25}$

Sebagaimana teori sistem, bahwa keluarga merupakan sebuah institusi yang dibangun dengan ikatan pernikahan sehingga membentuk suatu kesatuan yang dijalin oleh rasa cinta dan kasih sayang, saling berhubungan dan saling mempengaruhi. Maka, dengan konsep tersebut peneliti meyakini bahwa sebuah hubungan yang dijalin atas dasar cinta dan kasih sayang, maka

\footnotetext{
1996), 254. 2010), 80 .

${ }^{23}$ M. Quraish Shihab, Pengantin al-Qur'an: Kalung Permata Buat Anak-anakku (Jakarta: Lentera Hati,

${ }^{24}$ Shihab, Pengantin Al-Qur'an, 88.

${ }^{25}$ Shihab, Wawasan Al-Qur'an, 276.
}

${ }^{22}$ M. Quraish Shihab, Wawasan Al-Qur'an; Tafsir Tematik Atas Pelbagai Persoalan Umat (Bandung: Mizan, 
MA'ALIM: Jurnal Pendidikan Islam

Volume 1, Nomor 1, Juli 2020

akan menjadikan hubungan lebih nyaman, sebab segala sesuatu yang diikuti rasa cinta akan timbul ikhlas dalam dirinya. Dengan adanya rasa cinta, tidak akan mudah orang memutuskan hubungan begitu saja.

M. Quraish Shihab memberikan pengertian rahmah sebagai kondisi psikologis yang muncul di dalam hati akibat menyaksikan ketidakberdayaan, sehingga mendorong yang bersangkutan melakukan pemberdayaan. Maka masing-masing suami isteri akan sungguhsungguh, bahkan bersusah payah demi mendatangkan kebaikan bagi pasangannya serta menolak segala sesuatu yang mengganggu dan mengeruhkannya. ${ }^{26}$

Berdasarkan teori sistem bahwa keluarga terdiri dari unsur-unsur yang saling berhubungan satu sama lain sebagai suatu kesatuan, maka jika diibaratkan tubuh, apabila salah satu anggota merasa sakit, maka anggota tubuh yang lain juga akan merasakan sakit. Begitupun dengan sebuah hubungan, seseorang akan ikut merasakan kepedihan yang dirasakan oleh pasangannya. Maka, peneliti meyakini bahwa dengan adanya rahmah, keluarga akan menjadi tentram dan saling pengertian, sebab dengan saling mengerti, tidak akan saling menyalahkan, dan saling memahami bahwa manusia tidak ada yang sempurna, maka harus saling melengkapi kekurangan yang dimiliki oleh yang lain.

Untuk menilai suksesnya rumah tangga M. Quraish Shihab menyebutkan beberapa aspek yang dapat membedakannya, apakah keluarga tersebut bahagia atau tidak, yaitu: keseimbangan dan kesamaan. Maksudnya keseimbangan adalah keseimbangan antara kepentingan jasmani maupun rohani, keseimbangan antara hak dan kewajiban suami isteri, dan keseimbangankeseimbangan dalam segala aspek kehidupan dalam keluarga. Sedangkan kesamaan maksudnya, sama-sama hidup atau hidup bersama dengan langkah dan gerak yang sama, sama-sama manusia yang memiliki kesetaraan, sama-sama dewasa yaitu memiliki kematangan pikiran dan emosi sehingga melahirkan tanggung jawab, dan sama-sama cinta. ${ }^{27}$

Namun, berdasarkan teori keluarga sebagai sistem ada sepuluh aspek yang membedakan apakah keluarga itu bahagia atau tidak, sebagaimana yang dikutip Sri Lestari dari pendapat Davin H. Olson dan Amy K. Olson, aspek tersebut meliputi: aspek komunikasi, fleksibilitas, kedekatan, kecocokan kepribadian, resolusi konflik, relasi seksual, kegiatan waktu luang, kebersamaan dengan keluarga dan teman, pengelolaan keuangan, dan keyakinan spiritual.

\footnotetext{
${ }^{26}$ Shihab, Wawasan Al-Qur'an.., 277.

${ }^{27}$ Shihab, Pengantin Al-Qur'an, 109-128.
} 
MA'ALIM: Jurnal Pendidikan Islam

Volume 1, Nomor 1, Juli 2020

Peneliti menelaah bahwa pemikiran M. Quraish Shihab mengenai aspek yang membedakan keluarga yang bahagia atau tidak hanya menjelaskan aspek secara umum, belum menjelaskan aspek secara khusus. Jika aspek tersebut dijelaskan secara khusus, akan lebih mudah dalam mengidentifikasi apakah sebuah keluarga dikatakan bahagia atau tidak.

Selain aspek-aspek tersebut, M. Quraish Shihab juga menyebutkan beberapa fungsi keluarga, di antaranya: ${ }^{28}$ fungsi keagamaan, fungsi sosial budaya, fungsi cinta kasih, fungsi melindungi, fungsi reproduksi, fungsi sosialisasi dan pendidikan, fungsi ekonomi, dan fungsi pembinaan lingkungan. Apa yang diungkapkan oleh M. Quraish Shihab, sejalan dengan teori sistem, namun belum menyantumkan fungsi penentuan status dan fungsi pemeliharaan.

Jadi, berdasarkan uraian analisis di atas, peneliti menyimpulkan bahwa konsep sakinah mawaddah wa rahmah menurut $\mathrm{M}$. Quraish Shihab menurut kacamata teori sistem, bahwa keluarga sakinah adalah keluarga yang tenang, bukan keluarga yang tanpa masalah, melainkan keluarga yang dapat keluar dari masalah dengan penyelesaian yang baik. Sakinah terbentuk karena adanya mawaddah dan rahmah. Mawaddah adalah cinta sejati yang tidak akan memutuskan hubungan begitu saja, sebab hatinya begitu lapang dan kosong dari keburukan. Sedangkan rahmah adalah kondisi psikologis seseorang yang terjadi ketika ia melihat kepedihan pasangan, dan ia ikut merasakan kepedihan pasangan. Jika mawaddah dan rahmah telah menghiasi jiwa pasangan suami isteri dan terpelihara juga amanah yang mereka terima, maka pondasi rumah tangga kian kokoh dan sendi-sendinya akan semakin tegar, atau dengan kata lain, mawaddah dan rahmah merupakan prasyarat terbentuknya keluarga sakinah. Jadi, jika hilang salah satu saja di antara mawaddah dan rahmah maka, keluarga tidak sakinah.

\section{RELEVANSI KONSEP SAKINAH MAWADDAH WA RAHMAH DENGAN PENDIDIKAN ANAK}

Berdasarkan teori sistem, keluarga ada dua, yaitu keluarga inti dan keluarga batih. Keluarga inti adalah keluarga yang didasarkan atas ikatan perkawinan dan terdiri dari seorang suami, seorang isteri dan anak-anak mereka yang belum menikah. ${ }^{29}$ Anak-anak yang belum menikah masih menjadi tanggung jawab orang tua atau keluarga, apalagi anak-anak yang masih kecil, ia

\footnotetext{
${ }^{28}$ M. Quraish Shihab, Pengantin al-Qur'an, 165-179.

29 J. Dwi Narwoko dan Bagong Suyanto, Sosiologi,211.
} 
MA'ALIM: Jurnal Pendidikan Islam

Volume 1, Nomor 1, Juli 2020

membutuhkan kasih sayang dan pendidikan dari kelurganya. Maka menjadi kewajiban orang tua untuk memberikan kasih sayang dan pendidikan untuk anaknya.

Sejalan dengan konsep M. Quraish Shihab tentang sakinah mawaddah wa rahmah bahwa di dalam hubungan keluarga diperlukan adanya cinta dan kasih sayang, dengan begitu anak akan merasa nyaman tinggal bersama keluarga, apalagi di dalam keluarga bahagia dan utuh. Sebab ini akan mempengaruhi kepribadian anak.

Maka peneliti menelaah bahwa untuk mendidik anak langkah awalnya adalah dengan membuat anak merasa nyaman dulu tinggal di rumah dengan cara memberikan anak perhatian dan kasih sayang secukupnya, tidak perlu berlebihan, sebab akan membuat anak semakin manja, ajarkan anak untuk mandiri. Sebagaimana tujuan pendidikan dalam teori humanistik adalah membantu anak untuk mengembangkan dirinya yaitu membantu untuk mengenali diri dan lingkungannya sendiri serta membantu mewujudkan potensi-potensi yang ada pada diri anak.

Esensi manusia menurut teori humanistik pada dasarnya manusia adalah baik. ${ }^{30}$ Sebagaimana pandangan Islam tentang esensi manusia, bahwa manusia lahir dengan fitrah baik. Yang menjadikan manusia lebih baik atau lebih buruk tergantung orang tuanya. Bagaimana orang tua membangun relasi dengan anaknya. Hubungan dengan kulitas baik akan berpengaruh pada kepribadian positif anak.

Peneliti meyakini untuk membangun hubungan yang berkualitas baik berawal dari relasi atau hubungan antar suami isteri. Hubungan suami isteri yang memiliki kualitas baik juga akan berpengaruh pada hubungan mereka dengan anak-anaknya. Maka dengan begitu, akan mudah bagi keluarga untuk memberikan pendidikan yang baik terhadap anak-anaknya. Apalagi keluarga yang notabenenya berindikasi keluarga sakinah. Yaitu keluarga yang mampu mempertahankan mawaddah dan rahmah serta memelihara amanah di dalam keluarga.

Menurut Rogers, ada beberapa prinsip-prinsip pendidikan humanistik yang penting di antaranya: ${ }^{31}$

1. Manusia memiliki kemampuan belajar secara alami. Maksundnya bahwa motivasi belajar anak harus bersumber dari diri anak sendiri. Hal ini juga dipengaruhi dengan keadaan keluarga sendiri, bagaimana kualitas hubungan keluarga, apakah keluarga tersebut sakinah atau tidak,

${ }^{30}$ Sudarwan Danim dan Khairil, Psikologi Pendidikan; dalam Perspektif Baru (Bandung: Alfabeta, 2014), 23.

${ }^{31}$ Wasty Sumanto, Psikologi Pendidikan; Landasan Kerja Pemimpin Pendidikan (Jakarta: PT Rineka Cipta, 2006), 139-140. 
MA'ALIM: Jurnal Pendidikan Islam

Volume 1, Nomor 1, Juli 2020

sebab keluarga yang tenang dan tentram akan membawa pengaruh positif bagi perkembangan anak.

2. Belajar yang signifikan terjadi apabila subject matter dirasakan murid sesuai dengan maksudnya. Materi ajar yang diajarkan kepada anak haruslah menyesuaikan usia anak, sebab jika anak belum siap menerima materi, maka ia tidak akan memperoleh pengalamannya.

3. Cenderung menolak perubahan yang dirasa mengancam dirinya. Lingkungan keluarga sangat mempengaruhi proses pendidikan anak, keadaan yang terjadi pada lingkungan yang sekiranya mengancam diri anak, maka anak akan cenderung menolaknya. Jika melihat realitas, misal sebuah keluarga yang terancam gagal, hal tersebut sangat mempengaruhi pendidikan anak. Begitupun sebaliknya, keluarga sakinah akan mempengaruhi anak kepada perkembangan yang positif.

4. Lebih mudah merasakan ancaman dari tugas-tugas belajar dibanding ancaman dari luar. Proses belajar anak terjadi dalam keluarga, maka anak akan sangat peka dengan ancaman yang muncul, sebab keluarga merupakan lingkungan pertama yang dikenal anak. Proses belajar anak dikatakan berhasil apabila anak mampu mengenal dirinya sendiri dan lingkungannya.

5. Pengalaman didapat dari berbagai cara sehingga terjadilah proses belajar. Begitupun dengan pengalaman yang didapat anak dalam keluarga, apabila ada suatu hal yang terjadi dalam keluarga yang mana anak dapat memperoleh pemaknaan personalnya maka secara tidak langsung terjadi proses belajar. Bahkan proses belajar pun terjadi melalui cara tak terduga, misal terjadi keributan dalam keluarga, seperti orang tua yang selalu bertengkar, maka dari sana anak juga belajar.

6. Dengan melakukan secara langsung siswa dapat memperoleh pengalaman belajar yang bermakna. Anak didik merupakan aktor bukan reaktor dalam proses belajar, maka dengan melakukan sendiri anak akan memperoleh pengalamannya, sedangkan keluarga hanya berperan sebagai fasilitator. Meskipun sebatas fasilitator, keberdaan keluarga sangat mempengruhi pendidikan anak.

7. Jika anak didik dilibatkan dalam proses belajar dan bertanggung jawab atas proses tersebut, maka belajar akan menjadi lancar. Anak sebagai aktor harus terlibat langsung dengan proses belajar serta dibiasakan diberi tanggung jawab, agar proses belajar berjalan dengan lancar. Keluarga yang memberi teladan agar anak juga memiliki tanggung jawab. 
MA'ALIM: Jurnal Pendidikan Islam

Volume 1, Nomor 1, Juli 2020

8. Cara yang dapat memberikan hasil yang mendalam dan lestari apabila anak belajar dengan inisiatif sendiri. Anak yang belajar dengan inisiatif sendiri akan lebih bermakna dalam memperoleh pengalamannya, dan akan memperoleh hasil yang mendalam sehingga akan selalu teringat oleh si anak.

9. Kepercayaan diri, kemerdekaan dan kreatifitas lebih mudah dicapai terutama oleh siswa yang terbiasa mawas diri dan mengkritik dirinya sendiri. Anak yang dibiasakan mawas diri dan menilai diri sendiri oleh keluarganya, maka anak akan memiliki kepercayan diri dan mampu mengekspresikan apa yang dirasakannya sehingga dapat mengembangkan potensi yag dimilikinya.

10. Belajar sosial yang paling berguna adalah belajar mengenai proses. Hidup dalam lingkungan keluarga merupakan awal proses belajar sosial anak, karena keluarga merupakan lembaga pendidikan anak yang pertama dan utama. Keluarga merupakan wadah pertama kali anak bersosialisasi.

Jadi, berdasarkan pinsip-prinsip pendidikan tersebut peneliti meyakini bahwa keluarga sakinah memiliki pengaruh bagi pengembangan positif pendidikan anak. Teori yang diungkapkan Carl Roger yang mengembangkan satu filosofi pendidikan yang menekankan pentingnya pembentukan pemaknaan personal selama berlangsungnya proses pendidikan melalui upaya menciptakan iklim emosional yang kondusif untuk membentuk pemaknaan personal tersebut. Ia memfokuskan pada hubungan emosional antara pendidik dan peserta didik. ${ }^{32}$ Sedangkan Choms dan kawan-kawan percaya apabila para pendidik merasa tentram terhadap diri dan kemampuan mereka sendiri, maka mereka akan dapat memberikan perhatian pada orang lain.

Peneliti meyakini bahwa hal tersebut menunjukkan adanya pengaruh yang besar kehidupan keluarga terhadap pendidikan anak. Di dalam keluarga, orang tua adalah pendidik bagi anak-anak mereka. Apabila orang tua merasa tentram, maka hal tersebut juga akan dirasakan oleh anak. Karena proses pendidikan yang terjadi di dalam keluarga menekankan pentingnya pembentukan pemaknaan personal melalui penciptaan iklim emosional yang kondusif. Apabila iklim emosional dalam keluarga itu baik, katakalah keluarga itu sakinah, maka pemaknaan personal dalam proses belajar anak itu baik.

${ }^{32}$ Mahmud, Psikologi Pendidikan (Bandung: CV Pustaka Setia, 2010), 42. 
MA'ALIM: Jurnal Pendidikan Islam

Volume 1, Nomor 1, Juli 2020

Jadi, peneliti menarik kesimpulan bahwa keluarga yang menggunakan konsep sakinah mawaddah wa rahmah adalah keluarga yang mampu membentuk pendidikan yang baik untuk anak-anak mereka. Maka konsep ini relevan dengan pendidikan anak.

\section{KESIMPULAN}

Konsep Sakinah Mawaddah Wa Rahmah menurut M. Quraish Shihab adalah konsep keluarga bahagia yang penuh ketenangan di dalamnya dan yang dibentuk melalui potensi mawaddah dan rahmah yang dianugerakan Allah. Mawaddah dan rahmah merupakan prasyarat terbentuknya keluarga sakinah. Jadi, jika hilang salah satu saja di antara mawaddah dan rahmah maka, keluarga tidak sakinah.

Konsep Sakinah Mawaddah Wa Rahmah menurut M. Quraish Shihab relevan dengan pendidikan anak sebab keluarga yang menggunakan konsep sakinah mawaddah wa rahmah adalah keluarga yang mampu membentuk pendidikan yang baik untuk anak-anak mereka. Berdasarkan proses relasi antara keluarga dengan anak, sama-sama mendasari hubungan dengan rasa cinta dan kaih sayang. Serta untuk membentuk pendidikan yang berkualitas maka berawal dari membentuk keluarga yang sakinah mawaddah wa rahmah

Berdasarkan dari masalah,pembahasan serta analisis yang di lakukan, menurut peneliti masih banyak konsep keluarga yang lain yang perlu dikaji dan dipetik pelajarannya untuk menegembangkan dan meningkatkan kualitas pendidikan anak dalam keluarga. Sebab dalam keluarga lah kepribadian anak pertama kali dibentuk. Sehingga perlu diadakan penelitian lebih lanjut mengenai pendidikan anak dalam Islam.

\section{DAFTAR PUSTAKA}

Badan Litbang dan Diklat Kemenag RI. Modul Keluarga Sakinah Berperspektif Kesetaraan bagi penghulu, Penyuluh, dan Konselor BP4. Jakarta: Badan Litbang dan Diklat Kementrian Agama RI.

Badan Litbang dan Diklat Kementrian Agama RI. Keluarga Harmoni dalam Perspektif berbagai Komunitas Agama di Indonesia. Jakarta: Puslitbang Kehidupan Keagamaan Badan Litbang dan Diklat Kementrian Agama RI, 2011.

Danim, S. \& Khairil. Psikologi Pendidikan; dalam Perspektif Baru. Bandung: Alfabeta, 2014. 
MA'ALIM: Jurnal Pendidikan Islam

Volume 1, Nomor 1, Juli 2020

Departemen Agama RI. Al-Qur'an dan Tafsirnya Jilid VII. Departemen Agama RI, 2009.

. Al-Qur'an dan Tafsirnya Jilid I. Departemen Agama RI, 2009.

Al-Qur'an dan Tafsirnya Jilid II. Departemen Agama RI, 2009.

Al-Qur'an dan Tafsirnya Jilid X. Departemen Agama RI, 2009.

Hasbullah. Dasar-dasar Ilmu Pendidikan. Jakarta: PT Raja Grafindo Persada, 2005.

Khaeruman, Badri. Moralitas Islam. Bandung: CV Pustaka Setia, 2003.

Lestari, Sri. Psikologi Keluarga: Penanaman Nilai dan Penanganan Konflik dalam Keluarga. Jakarta: Kencana, 2013.

Mahmud. Psikologi Pendidikan. Bandung: CV Pustaka Setia, 2010.

Mustafa. M. Quraish Shihab Membumikan Kalam di Indonesia. Yogyakarta: Pustaka Pelajar, 2010.

Narwoko, J. Dwi \& Suyanto, Bagong. Sosiologi; Teks Pengantar dan Terapan. Jakarta: Kencana, 2004.

Nata, Abuddin. Metodologi Studi Islam. Jakarta: PT Raja Grafindo Persada, 2003.

--------------. Tokoh-tokoh Pembaharuan Pendidikan Islam Di Indonesia. Jakarta: Raja Grafindo Press. tt.

Rachman, M. Fauzi. Islamic Parenting. Jakarta: Erlangga, 2011.

Saebani, Beni Ahmad. Fiqh Munakahat 1. Cet. IV. Bandung: CV Pustaka Setia, 2009.

Shihab, M. Quraish. Wawasan Al-Qur'an; Tafsir Tematik Atas Pelbagai Persoalan Umat. Bandung: Mizan, 1996.

Pengantin al-Qur'an: Kalung Permata Buat Anak-anakku. Jakarta: Lentera Hati, 2010.

Tafsir al-Mishbāh: Pesan, Kesan dan Keserasian al-Qur'an, vol. 1, cetakan V. Jakarta: Lentera Hati, 2006.

Tafsir Al-Mishbah: Pesan, Kesan, dan Keserasian Al-Qur'an. Jakarta: Lentera Hati, 2003.

Sumanto, Wasty. Psikologi Pendidikan; Landasan Kerja Pemimpin Pendidikan. Jakarta: PT Rineka Cipta, 2006.

Willis, Sofyan S. Konseling Keluarga. Bandung: Alfabeta, 2013.

Yusdani. Menuju Fiqih Keluarga Progresif. Yogyakarta: Kaukaba, 2015. 